\title{
Abbreviations for Texts and Sources
}

Alticozzi, Relazione

Anderson, Constitutions 1723

Anderson, New Constitutions 1738

Ancient Constitutions 1731

Apologie pour l'ordre

$B N P$

Bottarelli, Exercises

Brennende Leuchter

Casanova, Mémoires

Catéchisme des francs-maçons

CGRN

Chetwood, Generous Freemason

Clare, On the Advantages
Relazione della compagnia de' liberi muratori estratta de varie memorie e indirizzata all'Abate Carl' Antonio Giuliani dal Cavalier Valerio Angiolieri Alticozzi (Naples, 1746)

Rev. Dr James Anderson, The Constitutions of the FreeMasons containing the History, Charges, Regulations, \&c. of that most Ancient and Right Worshipful Fraternity. For the Use of the Lodges (London, 1723) Rev. Dr James Anderson, The New Book of Constitutions of the Ancient and Honourable Fraternity of Free and Accepted Masons (London, 1738)

The Ancient Constitutions of the Free and Accepted Masons (London, 1731)

Apologie pour l'ordre des Franc- Maçons par Mr. N. membre de l'ordre avec deux chansons composées par Le Frère Amèricain (The Hague, 1742)

Brill's New Pauly. Encyclopedia of the Ancient World, 28 volumes (Leiden, 2002-2014)

F. Bottarelli, Exercises upon the different parts of Italian speech (London, 1778)

Der neu-aufgestechte Brennende Leuchter des Freymaurer-Ordens oder Eine sonderbare Historie dieser sonderbaren Brüderschaft bis auf unsere Zeiten. Nebst ihren innern und äussern Verfassungen, Statuten, Religion und Ordnungen wie auch eine zulängliche Kern und Auszug aller dazu gehörigen Schriften und gesammelten Reden (Leipzig, 1746)

G. Casanova, Mémoires (Paris, 1958), 3 volumes Catéchisme des Francs-Maçons Précédé d'un Abrégé de l'Histoire d'Adoniram, Architecte du Temple de Salomon, \& une Explication des Cérémonies qui s'observent à la Reception des Maîtres, le Signe, le Mot \& l'Attouchement, qui les distinguent d'avec les Apprentifs Compagnons (Jerusalem/Limoges, 1744)

Corpus of Greek Ritual Norms (online resource at CGRN@ulg.ac.be)

W. Chetwood, The Generous Freemason: or The Constant Lady with The Humours of Squire Noodle, and His Man Doodle. A Tragi-comi-farcical Ballad Opera in Three Acts (London, 1731)

M. Clare, On the Advantages Enjoyed by the Fraternity $=\mathrm{G}$. Oliver, The Golden Remains of the Early Masonic Writers (London, 1847), i. 74-88 
Clarke, Answer to the Pope's Bull

Cleland, Real Secret

\section{Critischer Brief}

De geheimen ... geopenbaart

de la Tierce, Histoire

Der Verrathene Orden

Dichiarazione dell'istituto

Dupuis, Origine

Étrenne au Pape

FGrH

Franklin, Constitutions 1734

GDLI

Grand Mystery
B. Clarke, An Answer to the Pope's Bull, with a Vindication of the Real Principles of Free-Masonry (Dublin, 1751) $=$ R. Péter ed., British Freemasonry 1717-1813, 5 vols (London, 2016), iv. 9-41

J. Cleland, The Way to Things by Words, and To Words by Things; Being A Sketch of An Attempt at the Retrieval of The Antient Celtic, or Primitive Language of Europe. To which is added, A succinct Account of the Sanscort, or Learned Language of the Bramins. Also Two Essays, the one, On the Origin of the Musical Waits at Christmas. The other On the Real Secret of the Free Masons (London, 1766 = Menston, 1968)

Critischer Brief eines Freimaurers über ein unter dem Titel: der verrathene Freimaurer-Orden neu herausgekommenes Buch (1745)

De geheimen der vrye-metselaars en der Mopsen geopenbaart (1745)

L.-F. de la Tierce, Histoire Obligations et Statuts de la très vénerable Confraternité des Francs- Macons Tirez de leurs Archives et Conformes aux Traditions les plus anciennes: Approuvez de toutes les Grandes Loges \& mis au jour pour l'Usage commun des Loges repandues sur la surface de la Terre (Frankfurt- am-Main, 1742). Der Verrathene Orden der Freimaurer (Amsterdam, 1745) Dichiarazione dell'istituto, e scopo de' liberi muratori dove si prende a confutare Il Candeliere acceso de' Liberi Muratori eretto di fresco (Rovereto, 1749)

C. Dupuis, Origine de tous les cultes ou Religion universelle, 3 volumes (Paris, 1795)

Étrenne au Pape, ou les Francs- Maçons vangés. Réponse à la Bulle, d'Excommunication Lancée par le Pape Benoit XIV. l'an 1751. fulminée à Naples, dattée du $X V$. des Kal. de Juin, la XI. Année de son pontificat, avec une Copie exacte de la ditte Bulle, \& une Traduction Françoise de la même pour la satisfaction des curieux en général. Conférence Epistolaire entre un Napolitain \& un Ministre de l'Eglise Romaine (The Hague, 1752) F. Jacoby ed., Die Fragmente der griechischen Historiker, 15 volumes (Berlin, 1923-1994)

The Constitutions of the Free-Masons containing the History, Charges, Regulations, \&c. of that most Ancient and Right Worshipful Fraternity. For the Use of the Lodges (Philadelphia, 1734)

Grande dizionario della lingua italiana, 23 volumes (Turin, 1961-2009)

The Grand Mystery of Free-masons Discover'd wherein are the several Questions put to them at their Meetings 
Gründliche Nachricht

Istituzione ... Cerimonie

Kuenen, Constitutions 1736

L'Adoption

La Franc-maçonne

L'Almanach des cocus

L'École des francs-maçons

Le Franc-Maçon

dans la République

Le Maçon démasqué

Le Nécrologe 1768

Le Nécrologe 1769

Le Parfait maçon and Installations: as also their Oath, Health, Signs and Points, to know each other by. As they were found in the Custody of a Free- mason who Dyed suddenly. And now Publish'd for the Information of the Publick (London, 1724)

Gründliche Nachricht von den Freymaurern nebst Angehängter Historischen Schutz-Schrifft (Frankfurt-amMain, 1738)

Istituzione, riti e cerimonie dell'ordine de' Francsmaçons ossian Liberi muratori (Venice, 1785)

J. Kuenen, Constitutions, histoires, lois, charges, règlements et usages de la très vénérable confrérie des acceptés francs-maçons. Tirés de leurs témoignages authentiques \& traditions fidèles de plusieurs siècles. Traduit de l'anglais par Jean Kuenen, Député GrandMaître des loges régulières en Hollande. Pour être lu à la réception d'un nouveau frère, suivant que le Maître ou ses Surveillants l'ordonneront (The Hague, 1736) = Coutura (1994), 229-284

L'Adoption ou la Maçonnerie des Femmes, en Trois Grades (The Hague/Geneva, 1775)

La Franc-Maçonne ou Révélation des mystères des francs-maçons par Madame *** (Brussels, 1744) L'Almanach des Cocus ou Amusemens pour le beau Sexe. Pour l'année M. DCC. XLI. Auquel on a joint un Recueil de Pieces sur les Francs-Maçons. Ouvrage instructif, epigrammatique, \& dedié à la Jeunesse amoureuse. Par un Philosophe Garçon (Constantinople, 1741)

L'École des Francs-Maçons (Jerusalem, 1748) = Coutura (1994), 173-228

Le Franc-Maçon dans la République ou Réfléxions Apologiques sur les Persécutions des Francs-Maçons par un Membre de l'Ordre avec une Lettre à Madame de *** ou on invite Plusieurs Auteurs Célèbres d'entrer dans le dit Ordre (Frankfurt-am-Main and Leipzig, 1746) Le Maçon Démasqué ou Le Vrai Secret des Francs Maçons, Mis au Jour dans toutes ses Parties avec Sincérité \& sans Déguisement (London, 1751)

Le Nécrologe des hommes célèbres de France par une société de gens de lettres. Année 1768 (Paris, 1768) Le Nécrologe des hommes célèbres de France par une société de gens de lettres. Année 1769 (Paris, 1769) Le Parfait Maçon ou Les véritables secrets des quatre grades d'Aprentis, Compagnons, Maîtres ordinaires \& Ecossois (Paris, 1744) 
Le Sceau rompu

Le Secret découvert

Le Secret des francs-maçons

Le Secret ... M. Uriot

Les Fra-Maçonnes

Les Francs-maçons écrasés

Letter from the Grand Mistress

Liberi Muratori Schiacciati

L'Ordre ... trahi

L'Origine ... des francs-maçons

Masonry Dissected
Le Sceau rompu ou la loge ouverte aux profanes par un franc Maçon (Cosmopolis, 1745)

Le Secret des Francs-Maçons, Entièrement découvert à une jeune dame de dix-sept ans par un faux frère de quatre-vingts ans; avec un discours prononcé en loge le 24 juin 1748, jour de la fête de Saint-Jean Baptiste, Patron de l'ordre, par le frère de $H^{* * *}$, orateur (Maastricht, 1748) = Coutura (1994), 129-138

Le Secret des francs-maçons, avec un recueil de leurs chansons, précédé de quelques piéces de poésie (1744) Le Secret des Francs-maçons mis en evidence par $M$. Uriot, membre des loges de l'Union et de l'Égalité (Frankfurt, 1744) = Coutura (1994), 65-90

Les Fra-Maçonnes. Parodie de l'Acte des Amazonnes; dans l'Opéra des Fêtes de l'Amour \& de l'Himen. En un Acte (Paris, 1754)

Les Francs-Maçons Écrasés; Suite du livre intitulé L'Ordre des Francs-Maçons Trahi. Traduit du Latin (Amsterdam, 1747)

A LETTER from the GRAND MISTRESS of the FEMALE FREE MASONS to GEORGE FAULKNER, Printer = The Works of Jonathan Swift D.D.D.S.P.D. with Notes Historical and Critical vol. 8 (Dublin, 1767), 323-332 I Liberi muratori schiacciati. Origine, dottrina, ed avanzamento della setta filosofica ora dominante. Opera composta da Uom pratichissimo delle loggie, ora tradotta dall'edizione di Amsterdam dal Sig. Abbate Don Pietro Mogas sacerdote spagnuolo confermata con note relative alle presenti rivoluzioni e novità di Europa dal Sig. Abbate D. Pietro Saverio Casseda pompejopolitano coll'aggiunta di un'Appendice in sostegna della Cattolica Religione. (Assisi, 1793)

L'Ordre des francs-maçons trahi et le secret des Mopses révelé (Amsterdam, 1745)

L'Origine et la déclaration mistérieuse des Francs-Maçons (Brussels, 1743)

S. Prichard, Masonry Dissected. Being a Universal and Genuine Description of all its Branches, from the Original to this Present Time: As it is deliver'd in the Constituted Regular Lodges, Both in City and Country, According to the Several Degrees of Admission: Giving an Impartial Account of their Regular Proceeding in Initiating their New Members in the whole Three Degrees of Masonry. Viz. I. Enter'd 'Prentice, II. Fellow-Craft, III. Master. To which is added the Author's Vindication of Himself. By Samuel Prichard, late Member of a Constituted Lodge, (London, 1730) 
Masonry Dissected, 7th ed

Masonry Farther Dissected

Meusnier de Querlon, Daphné

Naudot, Chansons notées

Nouveau catéchisme

$O C$

$O D N B$

Paperini

Pasquali

Pauly, RE

Picart, Cérémonies
S. Prichard, Masonry Dissected: Being a Universal and Genuine Description of all its Branches, from the Original to this Present Time: As it is deliver'd in the Constituted Regular Lodges, Both in City and Country, According to the Several Degrees of Admission: Giving an Impartial Account of their Regular Proceeding in Initiating their New Members in the whole Three Degrees of Masonry. Viz. I. Enter'd 'Prentice, II. Fellow-Craft, III. Master. With a new and exact List of Regular Lodges according to their Seniority and Constitution. To which is added the Author's Vindication of Himself. By Samuel Prichard, late Member of a Constituted Lodge, 7 th ed. (London, 1737)

Masonry farther dissected, or More Secrets of that Mysterious Society Revealed (London, 1738)

Meusnier de Querlon, Psaphion ou la courtisane de Smyrne suivi de Les soupers de Daphné (Nantes, 2001) Chansons notées de la très vénérable confrérie des maçons libres. Précédées de quelques pièces de poësie convenables au sujet et d'une marche. Le tout recueilli et mis en ordre par Fr. Naudot (City unknown, 1737) Nouveau catéchisme des francs- maçons. Contenant tous les mystères de la maçonnerie, épars et obmis dans l'ancien catéchisme, dans le livre intitulé le Secret des francs-maçons, etc. Et dans celui qui a pour titre, Le sceau rompu. Divisés en neuf chapitres, précédés de l'histoire d'Adoniram, architecte du temple de Salomon; avec de nouveaux desseins des loges de l'Aprentif-Compagnon, \& du Maître. Dédié au beau Sexe. Troisième édition (Jerusalem, 1749)

Opere complete di Carlo Goldoni edite dal municipio di Venezia nel Il centenario dalla nascità (Venice, 19071971)

Oxford Dictionary of National Biography, 60 volumes (Oxford, 2004)

Le Commedie del Dottore Carlo Goldoni-1757 Avvocato Veneziano fra gli Arcadi Polisseno Fegejo. Prima Edizione Fiorentina dall'Autore corretta, riveduta, ed ampliata, 10 volumes (Florence, 1753)

Delle Commedie di Carlo Goldoni Avvocato Veneto, 17 volumes (Venice, 1761-1778)

Paulys Realencyclopädie der classischen Altertumswissenschaft, 80 volumes (Stuttgart, 1890-1980)

B. Picart et al., Cérémonies et coutumes religieuses de tous les peuples du monde. Nouvelle édition (Amsterdam, 1736) 
Pivati s.v. Muratori Liberi

Pocket Companion

Principles of Free-Masonry

Polichinelle, Maître Maçon

Reception d'un Frey-Maçon

Relation apologique

Secret of Masonry

Secrets Revealed

Smith, G. On the Egyptian

Hieroglyphics

Smith, G. Use and Abuse

Smith, W. Pocket Companion

Stukeley, Palaeographia Sacra II

Superstitions de tous les peuples

The Free Masons
G. F. Pivati, Nuovo Dizionario Scientifico e Curioso Sacro-Profano vol. 6 (Venice, 1747) s.v. Muratori Liberi The Free-Mason's Pocket Companion (Edinburgh, 1752) The Principles of Free-Masonry Delineated (Exeter: Printed (and sold) by R. Trewman, behind the Guildhall, 1777) = E. Péter ed., British Freemasonry 1717-1813, 5 vols. (London, 2016), i. 187-240

Polichinelle, Maître Maçon. Représenté par les Marionettes de la Foire de Saint-Germain (Paris, 1744 = Paris, 1919)

Reception d'un Frey-Maçon = Gazette d'Hollande No. VI and VII for 21.1.1738 and 24.1.1738

Relation apologique de la Société des Francs-Maçons (Dublin, 1738)

S.P. The Secret of Masonry Known to all Men (London, January $1737 \mathrm{sic}$ )

The Secrets of the Free-Masons Revealed by a Disgusted Brother, 2nd ed. (London, 1759)

G. Smith, On the Egyptian Hieroglyphics = G. Oliver, The Golden Remains of the Early Masonic Writers (London, 1847), ii. 122-142

G. Smith, The Use and Abuse of Freemasonry: a work of the greatest utility to the brethren of the society, to mankind in general, and to the ladies in particular (London, 1783)

W. Smith, A Pocket Companion for Freemasons (London, 1735)

W. Stukeley, Palaeographia Sacra, or Discourses on Monuments of Antiquity that Relate to Sacred History Number II. A Dissertation on the Mysterys of the Antients in an Explication of That Famous Piece of Antiquity, the Table of Isis = Wellcome MS 4722

Superstitions de tous les peuples du monde, ou Tableau philosophique des erreurs et des foiblesses dans lesquelle les superstitions tant anciennes que modernes, ont précipité les hommes de la plupart des nations de la terre; ouvrage suivi d'un précis sur la merefolle, sur les bacchanales \& les orgies, sur le spectacle satyrique des grecs \& des romains, \& sur l'origine de l'association des francs-maçons. Nouvelle édition, enrichie de toutes les figures comprises dans l'ancienne édition en sept volumes, \& dans les quatre publiés par forme de supplément. Par une société de gens de lettres. Suite des cérémonies religieuses. Tome quatrième (Amsterdam/Paris, 1789)

The Free Masons. An Hudibrastick Poem: Illustrating the Whole History of the Ancient Free Masons, from the 
TO

Voltaire, $Q E$
Building the Tower of Babel to this Time. With their Laws, Ordinances, Signs, Marks, Messages, \&c. so long kept secret, Faithfully discover'd and made known. And the Manner of their Installation Particularly Describ'd (London, 1723)

C. Goldoni, Tutte le Opere, ed. G. Ortolani (Milan, 19351956)

Voltaire, Questions sur l'encyclopédie par des amateurs (1770-1772) 
